\title{
MODELLING PASSENGER LOYALTY TOWARDS APP-BASED MOTORCYCLE TAXI
}

\author{
Dwi Suhartanto $^{1}$, Michael Clemes ${ }^{2}$, Agustinus Februadi ${ }^{1}$, Tintin Suhaeni ${ }^{*}$, \\ and Zefanya Alanza Christabel Loveldy ${ }^{1}$ \\ ${ }^{1}$ Department of Business Administration, Politeknik Negeri Bandung, \\ Jl. Gegerkalong Hilir, Ds. Ciwaruga, Bandung, Indonesia \\ ${ }^{2}$ Faculty of Agribusiness and Commerce, Lincoln University, \\ Ellesmere Junction Street, Lincoln, Canterbury, New Zealand \\ *Corresponding author: tintin.suhaeni@polban.ac.id
}

Published online: 30 June 2020

To cite this article: Suhartanto, D., Clemes, M., Februadi, A., Suhaeni, T., \& Loveldy, Z.A.C. (2020). Modelling passenger loyalty towards app-based motorcycle taxi. Asian Academy of Management Journal, 25(1), 43-60. https://doi.org/10.21315/aamj2020.25.1.3

To link to this article: https://doi.org/10.21315/aamj2020.25.1.3

\begin{abstract}
This study evaluates the effect of both service quality and mobile application quality on passenger loyalty towards application-based motorcycle taxi (AMT) services. The data employed for this study were collected from 319 AMT service users in Bandung, Indonesia. To analyse the data, partial least squares structural equation modelling (PLS-SEM) was used to check the influence of both service quality and application quality on passenger loyalty and their indirect influence through passenger perceived value and passenger satisfaction. The result shows that the passenger perception of mobile app quality is an important driver of passenger loyalty towards AMT services. Further, this study suggests that the effect of both service quality and mobile app quality on passenger loyalty is via strengthening passenger perceived value and satisfaction. Finally, this study's findings reveal the important role of mobile app quality as the determinant of AMT service quality. This study provides a venue for AMT business managers to improve their business performance by developing both service quality and mobile app quality.
\end{abstract}

Keywords: Service quality, mobile application quality, loyalty, satisfaction, app-based motorcycle taxi

(C) Asian Academy of Management and Penerbit Universiti Sains Malaysia, 2020. This work is licensed under the terms of the Creative Commons Attribution (CC BY) (http://creativecommons. org/licenses/by/4.0/). 


\section{INTRODUCTION}

The rapid Internet technology development has enabled taxi firms to create online platform as a medium of communication and transaction with their customers. The availability of mobile application technology enables the taxi service providers to enlarge their market and enhance their customer relationship programs (NguyenPhuoc et al., 2019; Su et al., 2019). For taxi customers, this medium enables them to compare, select, and book the services easily. The benefits of the mobile apps for both passengers and taxi service providers have caused the expansion of the number of the app-based taxi service providers resulting in fierce competition (Nguyen-Phuoc, Oviedo-Trespalacios et al., 2020; Suatmadi et al., 2019). In this competitive atmosphere, understanding strategy to develop passenger loyalty is imperative as it could impact the business outcomes such as increasing revenue and reducing cost of operation (Lai \& Chen, 2011; van Lierop et al., 2018).

A factor which is widely recognised as contributing to loyalty is service quality. However, in an online business environment, such as in application-based motorcycle taxi (AMT) services, customers expect not only a high quality of ride service, but also a high quality of mobile app (Nguyen-Phuoc, OviedoTrespalacios et al., 2020; Suhartanto et al., 2019). Despite the importance of quality as the determinants of customer loyalty, scholars have only recently explored both qualities in a single study. More specifically, research works have begun scrutinising the combined effect of both service quality and mobile app quality, especially in the transport service context (Nguyen-Phuoc, Oviedo-Trespalacios et al., 2020). As research in this area is scant, scholars suggest to further explore the outcomes of both service quality and mobile app quality on customer post purchase behaviour (Alonso et al., 2018; Su et al., 2019). Including both service quality and mobile app quality in a single loyalty formation model will potentially extend our understanding on loyalty theory in transportation context which has lack of attention in the previous studies (Nguyen-Phuoc, Su et al., 2020; Vicente et al., 2020). Driven by this research gap, this study is intended to examine how both service quality and mobile app quality impact on passenger perceived value, passenger satisfaction, and passenger loyalty in AMT services. More specifically, this study proposes to: (1) gauge how the service quality and mobile app quality directly influences passenger loyalty; and (2) assess the indirect influence of both qualities on passenger loyalty via passenger perceived value and passenger satisfaction.

The motorcycle taxi is a common public transport using motorcycles, and generally, operate without fixed routes and for short distances. Due to its economical fare, the ability to manoeuvre in a congested traffic, and easy to book features, the AMT 
services are currently a vast and an important transport mode in many developing countries (Márquez et al., 2018; Nguyen-Phuoc et al., 2019; Su et al., 2019). This study is conducted in the Indonesian context due to its huge AMT market and attracting both local and global business players (Mutiarin, 2019). At present there are two main AMT players in Indonesia, Grab and Gojek, with both approximately having 2.5 million drivers (Cahyani, 2020). This business is a vast market in Indonesia; Gojek for instance serves around 3 million passengers daily (Franedya, 2019). In this huge and highly competitive environment, in order to survive and flourish, having loyal passengers is a must for any AMT service provider. Therefore, it is reasonable to study passenger loyalty towards AMT services in the Indonesian market.

\section{Loyalty in Transport Service}

In transport service, customer loyalty refers to a passenger's intention to utilise the transport service in the future based on their prior experiences (van Lierop et al., 2018; Vicente et al., 2020). Although the loyalty concept has been extensively discussed in the service literature, and seeing that it has only recently been discussed, researchers have not yet approved on how to measure it in transport (van Lierop et al., 2018). Most past researchers suggest that loyalty consists of two aspects: behavioural aspect which is associated to an individual's continual purchase or use of a service, and attitudinal aspect which is the consumer's commitment to behave favourably towards the services (Suhartanto et al., 2018). Related to these aspects, many authors note that loyalty should be predicated on the usage of transport services in the future and intention to promote and endorse the service (Zhao et al., 2014). These measurements of loyalty are generally employed in services industry, including in transport services. The reason of adopting this measurement is because intention in using the service is a representation of actual behaviour in the future (Lai \& Chen, 2011), while passengers who are straight-out endorse the service are an indication of their loyalty (Su et al., 2019; van Lierop et al., 2018).

In many literature works, there is a main assumption that only satisfied passengers with the service performance will continuously use the transport services and endorse it to other potential passengers (van Lierop et al., 2018; van Lierop \& El-Geneidy, 2016). However, scholars are convinced that variables of intention to use and willingness to recommend alone, are not enough to define loyalty. They often insist that measuring passenger loyalty should include passengers' satisfaction with the transport services. This happens because it is quite likely that some public transport passengers continue using the service because they do not have any other options even though they are dissatisfied with the service. This type of transport users uses transport services from a particular provider out of need 
rather than loyalty. These users may be likely to change their transport mode if presented with other alternative transport services. Zhao et al. (2014) believe that when satisfied passengers switch to other transport services because the preferred transport mode is available, it can cause the occurrence of a reverse effect. There may also be people who sincerely support a certain public transport in their community, even though they have never used, or will never use it. For these reasons, scholars tend to treat overall satisfaction as the determinant of passenger loyalty rather than as an element of passenger loyalty (van Lierop \& El-Geneidy, 2016; Zhao et al., 2014). Due to the continuous debate on how loyalty should be measured, examining passenger loyalty towards AMT services will contribute to help clarifying the issue.

\section{Service Quality in Transport Services}

The term service quality denotes an overall performance of the service to fulfil customer need (Parasuraman et al., 2005). Literature has widely discussed the importance of service quality in influencing customer behaviour and business performance in various industries, including in the transport service (Barabino et al., 2012). Past studies also consider service quality as the foremost factor of the customer experience in transportation (Bakti, 2015). Although past studies emphasise the importance of service quality, in terms of what attributes constitute service quality, there has been no consensus as to its constituent aspects. Therefore, one of the basic problems in understanding service quality in transport services is related to the measurement of service quality (Bakti, 2015). Many researchers in transport services have suggested models of service quality measurement, but there has not been any agreement on the measurement of service quality.

In public transport, researchers have attempted to develop a model of service quality that is deemed appropriate with the characteristics of transport services. In public transport service, Pedersen et al. (2011) developed a public land transport service quality model comprising of the dimensions of crews' attitude, on-board amenities, operational performance, and station performance. Another study in bus services conducted by Sánchez et al. (2007) adjusted SERVQUAL and generated a new service quality model called QUALBUS, encompassing the dimensions of tangibility, receptivity, reliability, empathy, and assurance. Lai and Chen (2011), in mass rapid transit service, offered a service quality model with two dimensions: physical environment and core service. In para transit services, Bakti (2015) proposes a service quality model, named as P-TRANSQUAL, including the dimensions of tangible, personnel, comfort, and reliability. A recent study in taxi services identifies three dimensions of taxi service quality: taxi station, taxi, and driver (Shaaban \& Kim, 2016). Another study in taxi service assesses the service 
quality with a single dimension (Alonso et al., 2018). The identified dimensions and measurement of the service quality in public transport show that the result is divergent. As the motorcycle taxi is unique and differs from the other types of public transport, assessing its service quality measurement will contribute to shed light on the service quality measurement in public transport.

Due to its important role, service quality has been empirically examined in various transport studies. Zhao et al. (2014) confirm that customers' transport mode choice is mainly dictated by the service quality factor. Lai and Chen (2011) suggest that the quality of service is a major determinant of passenger behavioural intention, an indicator of loyalty. Another study to explore customer behaviour in the transport setting reports the significant service quality role in affecting passenger satisfaction and passenger intention to reuse and to endorse the transport services (Barabino et al., 2012). Lastly, Nguyen-Phuoc, Su et al. (2020) report that perceived service quality has direct effect on passenger loyalty toward ride-hailing taxi services. Nevertheless, none of the studies in the AMT service identified have assessed service quality as the determinant of passenger post purchase behaviour. As the difficulty in the generalisation of a study in one environment to another environment, it is necessary to assess the impact of service quality on passenger loyalty in the context of AMT services. Referring to past studies, it is logical to assume the following hypothesis:

\section{$\mathrm{H}_{1}$ : Service quality positively influences passenger loyalty}

\section{Mobile Application Quality}

Mobile application quality, referred to as electronic service quality in some literature, refers to the performance of the mobile application in facilitating customer purchasing the products and services (Weng et al., 2017). This description denotes that mobile application quality is the customers' inclusive assessment of the electronic services offerings. In online transport, passengers require quality service of mobile application when booking a product or service (Weng et al., 2017). Thus, the mobile application quality is a crucial factor for the firms to market their transport services. This is particularly important in businesses such as online taxi services, where the interaction between the firms and their customers is solely through the mobile application. Jeon and Jeong (2017) suggest that upholding the mobile app quality is imperative to retain customers, persuade them to use the application, and finally to secure their loyalty. Consequently, keeping a high-quality mobile application is pivotal for the online business success. 
For online businesses, a website or a mobile application is equal to a distribution channel in conventional business. Studies on e-service quality mainly focus on two issues, the dimensionality and its antecedents and consequences. An important study on e-service dimensionality was conducted by Parasuraman et al. (2005) resulting in an e-service quality measurement instrument called the ES-QUAL, consisting of four dimensions: system availability, efficiency, privacy, and fulfilment. Subsequent researchers offer additional dimensionality models consisting of varied dimensions (Jeon \& Jeong, 2017; Silalahi et al., 2017). In terms of the mobile service quality consequences, studies have progressively considered the link between customer interaction with the mobile application and their subsequent behaviours. Previous studies suggest that customer loyalty is driven by customer experience with the mobile service quality (Jeon \& Jeong, 2017). Therefore, the association between mobile application quality and passenger loyalty is assumed as follows:

\section{$\mathrm{H}_{2}$ : Mobile app quality positively influences passenger loyalty}

Literature has reported the association between service quality and online quality; however, few studies have assessed the consequences of mobile app quality on service quality in transport service (Su et al., 2019). The spillover theory postulates that experiences in a certain life stage will affect other areas of life (Sirgy et al., 2001). Based on this theory, a customer's experiences in one part of their consumption process could affect his or her experience in the other parts of the consumption process. In the AMT context, it is expected that the customers' experience with mobile app service will spill over and affect their perception towards the service quality. Although the opposite direction could also be possible, in AMT services, passengers book the service first via the mobile app before riding the motorcycle taxi. Thus, it is suggested that the customer experience with the quality of mobile app service will influence service quality of the AMT service.

$\mathrm{H}_{3}$ : Mobile app quality positively influences service quality

\section{Passenger Perceived Value}

The term value perceived by customer is associated with a relative assessment between benefits and sacrifices related to the product or services offering. The conceptual basis of perceived value is equity theory which postulates that it is the proportion between the provider's outcome and the consumer's input. Passengers feel treated fairly if they feel that the proportion between the fare and experiences with the services is equivalent. The perceive value's importance in onlinebased business such as AMT is because passengers can easily compare service 
features and prices. Scholars report that service quality significantly influences perceived value (Zhao et al., 2014). Further, they proposed the perceived value model in public transport services to examine the drivers of passengers repurchase intention. Their studies indicate that perceived value, determined by perceived cost compared to perceived benefit, is an important determinant of passenger's intention to repurchase. A similar result is reported in other studies in the public transport setting which found that value perceived by passengers influences their satisfaction and behavioural intention (Lai \& Chen, 2011). Finally, in a review of literature in public transport, van Lierop et al. (2018) conclude that the quality of service is an antecedent of passenger perceived value and is an important element for both passenger satisfaction and loyalty. This discussion leads to the hypotheses on the relationships between quality, value, and loyalty in AMT services as follows:

$\mathrm{H}_{4}$ : Mobile app quality positively influences passenger perceived value

$\mathrm{H}_{5}$ : Service quality positively influences passenger perceived value

$\mathrm{H}_{6}$ : Perceived value positively influences passenger loyalty

\section{Passenger Satisfaction}

The satisfaction with travel experience concept is well discussed and used in transport literature. Lai and Chen (2011) define satisfaction in the transport context as passengers' experience with a transport service associated with their prior expectations. When passengers perceive that the transport service performance is greater than their expectation, they are satisfied. The literature in transport suggests that the quality of transport service affects passenger satisfaction (van Lierop et al., 2018; van Lierop \& El-Geneidy, 2016). Other scholars (Lai \& Chen, 2011; $\mathrm{Su}$ et al., 2019) report that passenger satisfaction influences passenger loyalty. Passengers who are satisfied with their travel service consumption may intend to repurchase the transport service in the future, endorse the transport services to other potential customers, and voice positive remarks about the transport services. Lastly, Nguyen-Phuoc, Su et al. (2020) report that perceived service quality has direct effect on passenger satisfaction. This discussion implies that in the AMT service, customer satisfaction is related to service quality, mobile app quality, and behavioural intention.

$\mathrm{H}_{7}$ : Mobile app quality positively influences passenger satisfaction

$\mathrm{H}_{8}$ : Service quality positively influences passenger satisfaction

$\mathrm{H}_{9}$ : Perceived value positively influences passenger satisfaction 
$\mathrm{H}_{10}$ : Passenger satisfaction positively influences passenger loyalty

The proposed passenger loyalty model towards AMT services with its determinants is depicted in Figure 1.

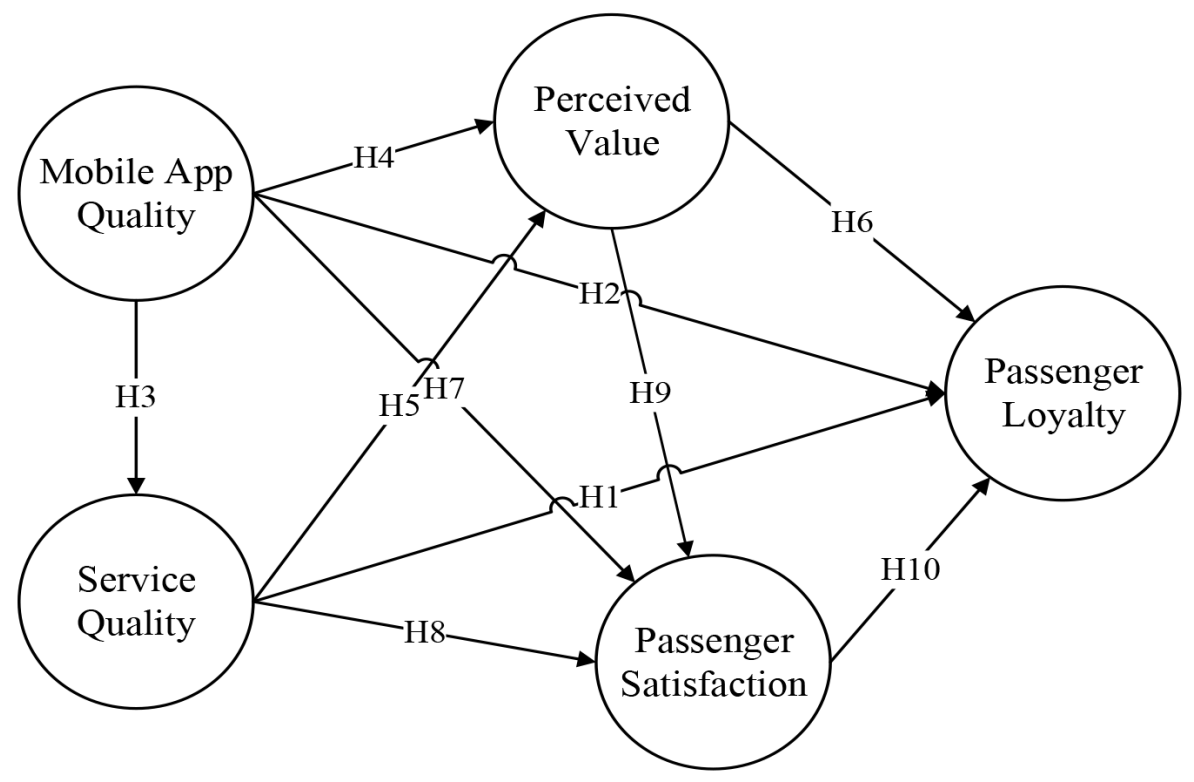

Figure 1. The proposed passenger loyalty model

\section{RESEARCH METHODS}

\section{Scale Measurement}

Literature seems to be silent in evaluating this issue in AMT services; thus, the measurement instrument for passenger experience with AMT service was developed through focus group discussion. Two focus group discussions, each consisting of seven AMT customers, were conducted in a state polytechnic in Bandung to generate the initial instruments of service quality toward AMT services. The instruments identified were then consulted to the experts in transportation to improve the face validity and to get verification on the suitability of the instruments. Following this process, 10 indicators of service quality of AMT service are generated (see Table 1), reflecting the components of comfort, tangible, personnel, and reliability.

The mobile app quality is measured with four items: the application being easy to operate; the application is helpful for planning travelling; the cost well informed; 
and application easy to be understood adapted from previous study (Silalahi et al., 2017; Weng et al., 2017). Perceived value was assessed with three items (Lai \& Chen, 2011). Two items adapted from past studies were used to gauge passenger satisfaction (Barabino et al., 2012; Pedersen et al., 2011). This study proposes that passenger loyalty as a composite consisting of both attitude and behaviour elements. This construct is measured with three items, intention to repurchase, recommend, and inform positive things (Lai \& Chen, 2011; Su et al., 2019).

\section{Sampling}

The sample used in this study were students who are AMT service users in Indonesia. While cab taxi passengers normally vary in term of their age, due to the safety risk of motoring, the majority of motorcycle taxi passengers in Indonesia are dominated by young customers, with the majority $(76 \%)$ being students (Silalahi et al., 2017). Therefore, following Nordfjærn et al.'s (2019) study in transport service, this study uses students as sample. As identifying the total population of AMT service users is almost impossible, this study uses purposive sampling, as it can enable researchers to gather a population representative sample. A selfadministered list of questionnaires, in the Indonesian language, was distributed to 400 AMT passengers. The survey was conducted in several universities and polytechnics in Bandung city, from January to March 2019. Prior to handing the questionnaires, to ensure that the respondents were suitable for this study, they were asked whether they had experience in using AMT service in the past four weeks. This study limits a period of four weeks because in that period the consumers were expected to still be able to recall their experience in consuming the AMT service. Of the distributed questionnaires, 331 were returned, but 15 of them were excluded for analysis due to incomplete data. With this sample size, the requirement in which data must be at least ten times of the indicator for running PLS (Kline, 2015) is satisfied as this study uses 22 indicators. Of the 331 participants, $97(30 \%)$ are male and $222(70 \%)$ are female. The female majority in

this study corroborates with other studies reporting that females are the majority of the motorcycle taxi passengers (Márquez et al., 2018). The average use of the service per week is $199(63 \%)$ less than 3 times, $82(26 \%)$ between 3 to 5 times, and $37(12 \%)$ more than 5 times.

\section{Data Analysis}

To analyse the data, this study applies a two-stage process. First, checking the measurement model to assess the suitability of the variable constructs. In this stage, the model was examined by applying confirmatory factor analysis using variance based PLS. The second stage assesses the structural model using PLS 
to test the proposed hypotheses. PLS was applied as it enables a researcher to assess latent constructs using a small and medium sample size and non-normality distributed data (Hair et al., 2017). Additionally, PLS is a noted technique to estimate coefficient paths in structural models (Henseler et al., 2015). Kock and Lynn (2012) recommended full collinearity variance inflation factors (VIFs) to assess for common method variance. Using this recommendation, VIFs test resulted the value of 1.894, less than the cut-off value of 5 (Hair et al., 2017). Thus, common method variance was is not an issue for the study.

\section{RESULTS}

\section{Measurement Model}

To assess the construct validity this study assesses factor loading, average variance extracted (AVE), and composite reliability (CR). As shown in Table 1, all indicators of validity are satisfied and the recommended cut-off value factors loading of more than 0.7 , except for item "The motorcycle looks good." Thus, this item is excluded in the subsequent analysis. The CR and Cronbach's alpha have a value of more than 0.7, and AVE of more than 0.5, indicating that the construct variables are reliable (Hair et al., 2017).

Table 1

Loading of the item measurement model, CR, and AVE

\begin{tabular}{lcccc}
\hline Construct/indicator & Loading & Cronbach & CR & AVE \\
\hline Service quality & & 0.871 & 0.899 & 0.528 \\
Rider rides the motorcycle well & 0.734 & & & \\
The ride duration is within the expected time & 0.793 & & & \\
The motorcycle is well maintained & 0.780 & & & \\
The motorcycle ride is comfortable & 0.737 & & \\
I feel secure using motorcycle taxi & 0.720 & & \\
The motorcycle looks good & 0.498 & & \\
The rider picks me up on time & 0.747 & & \\
I feel safe when I have the ride & 0.871 & & \\
Motorcycle equipment is good & 0.819 & & \\
Rider is able to avoid traffic jams & 0.745 & & \\
\end{tabular}

(continued on next page) 
Table 1 (continued)

\begin{tabular}{|c|c|c|c|c|}
\hline Construct/indicator & Loading & Cronbach & $\mathrm{CR}$ & AVE \\
\hline Mobile app quality & & 0.724 & 0.830 & 0.554 \\
\hline $\begin{array}{l}\text { Information in the mobile app is easily } \\
\text { understood }\end{array}$ & 0.771 & & & \\
\hline The mobile app can be used with ease & 0.794 & & & \\
\hline The fare is well indicated & 0.804 & & & \\
\hline The mobile app is helpful in making travel plan & 0.783 & & & \\
\hline Perceived value & & 0.792 & 0.879 & 0.709 \\
\hline Overall value & 0.765 & & & \\
\hline The cost is worth the ride & 0.884 & & & \\
\hline The fare is reasonable & 0.873 & & & \\
\hline Passenger satisfaction & & 0.884 & 0.945 & 0.896 \\
\hline The service is beyond expectation & 0.944 & & & \\
\hline Overall satisfaction & 0.950 & & & \\
\hline Passenger loyalty & & 0.821 & 0.893 & 0.736 \\
\hline Intention to inform positive thing & 0.875 & & & \\
\hline Intention to recommend & 0.887 & & & \\
\hline Intention to repurchase & 0.810 & & & \\
\hline
\end{tabular}

Henseler et al. (2015) recommend Heterotrait-Monotrait method to judge the construct's discriminant validity with cut-off value of not more than 0.9. Using this recommendation, the discriminant validity of the constructs tested is satisfied as all Heterotrait-Monotrait values are less than 0.9. These values suggest that the discriminant validity requirement between the variables is satisfied.

\section{Structural Model}

The path coefficients assessment, as Hair et al. (2017) recommended was conducted by using a bootstrapping procedure with 5000 iterations. Following Hair et al.'s (2017) recommendation, this study uses the goodness of fit (GoF) index to gauge the model fit. The GoF assessment result indicates that the fitness of the model is good as the GoF value is 0.564 . Further, to check the approximate fit indices, normal fit index (NFI) and standardised root mean square residual (SRMR) were applied. The results show that SRMR has a value of 0.070 (lower than the suggested value of 0.8 ) and NFI has a value of 0.762 , lower than the suggested minimum level of 0.9 (Hair et al., 2017). Although the NFI criteria is not fully 
satisfied, the other criteria are satisfied, thus it can be said that the fitness of the model is relatively fulfilled.

Succeeding the goodness of fit analysis, the hypothesised relationships were tested. The predictor explanatory power of the respective constructs is indicated by the corrected $R^{2} \mathrm{~s}$. The data analysis result shows that the mobile app quality predict $42.4 \%\left(R^{2}=0.424\right)$ of service quality, both mobile app and service quality explain $41.4 \%\left(R^{2}=0.414\right)$ of perceived value. The service quality, mobile app quality, and perceived value explain $53.1 \%\left(R^{2}=0.531\right)$ of passenger satisfaction. Lastly, all of the exogenous variables explain $43.8 \%\left(R^{2}=0.438\right)$ of passenger loyalty. As the range of $\mathrm{R} 2$ is between 0.424 and 0.531 , the model validity of this study can be classified as between moderate and substantial (Hair et al., 2017).

Besides the $R^{2}$ value, scholars maintain that researchers should use predictive sample reuse $\mathrm{Q}^{2}$ to identify the effectiveness of predictive relevance (Henseler et al., 2015). $\mathrm{Q}^{2}$ indicates how well the data can be reassembled by employing the PLS parameters and the proposed model. Based on the procedure of blindfolding, the result of data analysis shows that the predictive relevance $\left(\mathrm{Q}^{2}\right)$ for endogenous variables are acceptable as their values are positive (Hair et al., 2017). Table 2 shows that, from the t-values, the result is simply that all paths of the variable relationships are significant, but for the link between service quality and passenger loyalty $(\beta=0.103, p>0.05)$. Thus, hypothesis $H_{1}$ is not verified, while other hypotheses are supported.

Table 2

Hypotheses test results

\begin{tabular}{|c|c|c|c|c|c|c|}
\hline \multirow{2}{*}{ Hypothesis/path } & \multicolumn{2}{|c|}{ Direct effect } & \multicolumn{2}{|c|}{ Indirect effect } & \multicolumn{2}{|c|}{ Total effect } \\
\hline & $\beta^{* * *}$ & t-value & $\beta^{* * *}$ & t-value & $\beta$ & t-value \\
\hline $\begin{array}{l}\mathrm{H}_{1}: \text { Service quality } \rightarrow \\
\text { Loyalty (NS) }\end{array}$ & 0.103 & 1.725 & 0.180 & $4.826^{* *}$ & 0.283 & $4.781^{* *}$ \\
\hline $\begin{array}{l}\mathrm{H}_{2}: \text { Mobile app quality } \rightarrow \\
\text { Loyalty }(\mathrm{S})\end{array}$ & 0.133 & $2.309^{*}$ & 0.400 & $9.171^{* *}$ & 0.532 & $13.231^{* *}$ \\
\hline $\begin{array}{l}\mathrm{H}_{3}: \text { Mobile app quality } \rightarrow \\
\text { Service quality (S) }\end{array}$ & 0.652 & $19.468^{* *}$ & - & - & 0.652 & $19.468^{* *}$ \\
\hline $\begin{array}{l}\mathrm{H}_{4}: \text { Mobile app quality } \rightarrow \\
\text { Perceived value (S) }\end{array}$ & 0.406 & $7.198^{* *}$ & 0.196 & $4.909^{* *}$ & 0.602 & $15.096^{* *}$ \\
\hline $\begin{array}{l}\mathrm{H}_{5}: \text { Service quality } \rightarrow \\
\text { Perceived value }(\mathrm{S})\end{array}$ & 0.300 & $4.741^{* *}$ & - & - & 0.300 & $4.741^{* *}$ \\
\hline $\begin{array}{l}\mathrm{H}_{6}: \text { Perceived value } \rightarrow \\
\text { Loyalty }(\mathrm{S})\end{array}$ & 0.313 & $5.645^{* *}$ & 0.067 & $3.063^{* *}$ & 0.380 & $7.411^{* *}$ \\
\hline
\end{tabular}


Table 2 (continued)

\begin{tabular}{|c|c|c|c|c|c|c|}
\hline \multirow{2}{*}{ Hypothesis/path } & \multicolumn{2}{|c|}{ Direct effect } & \multicolumn{2}{|c|}{ Indirect effect } & \multicolumn{2}{|c|}{ Total effect } \\
\hline & $\beta^{* * *}$ & t-value & $\beta^{* * *}$ & t-value & $\beta$ & t-value \\
\hline $\begin{array}{l}\mathrm{H}_{7}: \text { Mobile app quality } \rightarrow \\
\text { Satisfaction (S) }\end{array}$ & 0.269 & $4.969^{* *}$ & 0.364 & $8.466^{* *}$ & 0.633 & $21.124^{* *}$ \\
\hline $\begin{array}{l}\mathrm{H}_{8}: \text { Service quality } \rightarrow \\
\text { Satisfaction (S) }\end{array}$ & 0.287 & $5.233^{* *}$ & 0.088 & $3.892^{* *}$ & 0.375 & $7.138^{* *}$ \\
\hline $\begin{array}{l}\mathrm{H}_{9}: \text { Perceived value } \rightarrow \\
\text { Satisfaction }(\mathrm{S})\end{array}$ & 0.293 & $6.144^{* *}$ & - & - & 0.293 & $6.144^{* *}$ \\
\hline $\begin{array}{l}\mathrm{H}_{10}: \text { Satisfaction } \rightarrow \\
\text { Loyalty }(\mathrm{S})\end{array}$ & 0.228 & $3.414^{* *}$ & - & - & 0.228 & $3.414^{* *}$ \\
\hline
\end{tabular}

Note: ${ }^{*}$ significant at $p<0.05,{ }^{* *}$ significant at $p<0.01 ;{ }^{* * *}$ standardised; (NS): Not supported; (S): Supported

To obtain an overall picture of the effect of exogenous variables on endogenous variables, it is important to assess the total effect of the variables. Total effect is the sum of direct effects and indirect effects. Table 2 shows that all exogenous variables significantly affect loyalty, with mobile app quality having the most with total effect of $\beta=0.532(p<0.01)$.

\section{DISCUSSION AND THEORETICAL IMPLICATION}

This study shows the importance of mobile app quality in influencing passenger loyalty toward AMT services. Besides the direct effect on passenger's loyalty, this factor indirectly influences passenger loyalty through perceived value and passenger satisfaction. In addition to directly affecting passenger loyalty, this study suggests that the mobile app quality influences passenger loyalty through strengthening the customer's perceived values and the customers' level of satisfaction. This study corroborates with past studies (Su et al., 2019; Weng et al., 2017) in the transport service that reveals the important role of online app quality in determining customer behavioural intention. When the application is of high quality, customers tend to repurchase and recommend the AMT service in the future (Min et al., 2019). This is also reflected in their behaviour of continuously using the transport mode. This finding implies that mobile app quality is a critical component in the AMT service. Therefore, from a theoretical perspective, this study offers a significant contribution regarding loyalty in public transport service. While existing literature (Nguyen-Phuocet, Su al., 2020; van Lierop et al., 2018) identifies service quality, perceive value, and satisfaction as building blocks of loyalty, the current study offers a new understanding that, in AMT service, mobile app quality should be treated as another building block of passenger loyalty. 
In terms of service quality, this study reveals that this quality is essential in determining perceived value and satisfaction, but contrary to past studies in public transport (Su et al., 2019), it has an insignificant direct effect towards passenger loyalty. However, looking at its overall influence on passenger loyalty, service quality has a significant total impact on passenger loyalty. This result infers that service quality strengthens passenger's perceived value and passenger satisfaction which subsequently creates passenger loyalty towards the AMT services. This finding means that, high service quality per se does not encourage a motorcycle taxi passenger to reuse or recommend the AMT service. However, a high service quality will make passengers perceive the value of the service more highly and thus more satisfied with the AMT services. The explanation of this finding might be because the service quality offered by service providers is perceived by customers as a standard service (Min et al., 2019). Thus, the service difference between AMT providers is fairly indistinguishable. This finding supports other studies (Dean \& Suhartanto, 2019; Nguyen-Phuoc, Su et al., 2020) finding that current service customers pursue more than simply quality service. They seek an experience quality that they are part of and where they are active participants in creating the service value.

This study reveals an important finding in term of the link between mobile app quality and service quality, which suggests that the quality of mobile app influences service quality toward AMT. This result corroborates with the service process. In the AMT service, although transport is the fundamental element to satisfy passenger need, the process of consuming the transport service starts from when the customers search and order the service through the mobile application. Therefore, the customer experience with the mobile app quality will influence customer perception of the service quality. This finding verifies the study in other service environment that conclude that the service delivered influences the customer experience with other transport services (Márquez et al., 2018; Su et al., 2019). From a theoretical perspective, this significant link between the quality of mobile app and service quality provides a new understanding by supporting the Spillover Theory that postulates that experience in one service will influence the person's experience with other related services.

\section{MANAGERIAL IMPLICATION}

The importance of mobile app quality in determining passenger loyalty towards AMT services provide an avenue for managers of online taxi providers to have an impetus to improve their business performance. This study suggests that having an excellent mobile app service quality is essential. In the online environment, the 
transport service is intangible. Unlike the traditional public transport, consumers in the online service cannot taste, touch, smell, and see the transport offered. Rather, consumers assess the service quality by relying on the picture and the given description of the services in the mobile application. Hence, to maximise the degree of customer intention to reuse and recommend the service, clear and understandable information should be provided in the application. Moreover, comprehensive information with reasonable explanations should be given, such as the width and depth of the service offerings.

This study recommends that AMT managers need to be aware that satisfying and providing value experience service is also an important strategy to develop favourable passenger loyalty. It is essential for AMT business managers to pay attention to both mobile app quality as well as high service quality. As the service quality is mainly determined by the taxi driver, this study suggests that the AMT managers focus their attention on its human factor (i.e., taxi driver). In order to create passenger satisfaction, this study recommends that the managers of AMT businesses have to deliver a high level of service quality by employing drivers who are capable of driving safely and in a timely manner, understanding passenger needs, being friendly to the passengers, and understanding well the city traffic in order to avoid the traffic jam. The development of such skills and capabilities of the AMT staff can be achieved by offering suitable training for the drivers as well as providing motivational rewards.

\section{LIMITATION AND FUTURE RESEARCH}

This study is focused on students as AMT service users in Bandung, Indonesia. A further research is suggested to evaluate the theoretical relationships identified in this study in other samples locations. The replication of this study would be valuable in assessing the generalisability of the theoretical relationship identified in this study. Next, the passenger loyalty variance explained suggests that there are other variables not included in this study. Service fairness, perceived risk, and trust potentially affect customer loyalty; thus, to improve the prediction of passenger loyalty, the future studies could add these loyalty determinants into the proposed model. Last, the passenger loyalty model examined in this research supposes the causal effect in the relationship between variables tested. The results of causaleffect test reported in this study should be considered carefully as the data is collected using a cross-sectional method, making this study neither experimental nor longitudinal. The future studies could use longitudinal data to more precisely represent the changes through a period of time. 


\section{REFERENCES}

Alonso, B., Barreda, R., dell'Olio, L., \& Ibeas, A. (2018). Modelling user perception of taxi service quality. Transport Policy, 63, 157-164. https://doi.org/10.1016/ j.tranpol.2017.12.011

Bakti, I.G.M.Y.S.S. (2015). P-TRANSQUAL: A service quality model of public land transport services. International Journal of Quality \& Reliability Management, 32(6), 534-558. https://doi.org/10.1108/IJQRM-06-2013-0094

Barabino, B., Deiana, E., \& Tilocca, P. (2012). Measuring service quality in urban bus transport: A modified SERVQUAL approach. International Journal of Quality and Service Sciences, 4(3), 238-252. https://doi.org/10.1108/17566691211269567

Cahyani, D.R. (2020). Berapa jumlah pengemudi Ojek online di Indonesia? Tempo, 26 February. https://bisnis.tempo.co/read/1312829/dihentikan-sementara-kemenhub -penerbangan-umrah-masih-normal

Dean, D., \& Suhartanto, D. (2019). The formation of visitor behavioral intention to creative tourism: The role of push-pull motivation. Asia Pacific Journal of Tourism Research, 24, 393-403. https://doi.org/10.1080/10941665.2019.1572631

Franedya, F. (2019). Fakta-fakta yang orang tidak tahu soal Gojek, 2 juta driver? CNBC Indonesia, 16 February. https://www.cnbcindonesia.com/tech/20190405134149 -37-64882/fakta-fakta-yang-orang-tidak-tahu-soal-gojek-2-juta-driver

Hair, J.E., Hult, G.T., Ringle, C.M., \& Sarstedt, M. (2017). A primer on partial least squares structural equation modeling (PLS-SEM) ( 2 nd ed.). Sage.

Henseler, J., Ringle, C.M., \& Sarstedt, M. (2015). A new criterion for assessing discriminant validity in variance-based structural equation modeling. Journal of the Academy of Marketing Science, 43(1), 115-135. https://doi.org/10.1007/s11747-014-0403 $-8$

Jeon, M.M., \& Jeong, M. (2017). Customers' perceived website service quality and its effects on e-loyalty. International Journal of Contemporary Hospitality Management, 29(1), 438-457. https://doi.org/10.1108/IJCHM-02-2015-0054

Kline, R.B. (2015). Principles and practice of structural equation modeling (4th ed.). The Guilford Press.

Kock, N., \& Lynn, G. (2012). Lateral collinearity and misleading results in variancebased SEM: An illustration and recommendations. Journal of the Association for Information Systems, 13(7), 546-580.

Lai, W.-T. \& Chen, C.-F. (2011). Behavioral intentions of public transit passengers-The roles of service quality, perceived value, satisfaction and involvement. Transport Policy, 18(2), 318-325. https://doi.org/10.1016/j.tranpol.2010.09.003

Márquez, L., Pico, R., \& Cantillo, V. (2018). Understanding captive user behavior in the competition between BRT and motorcycle taxis. Transport Policy, 61, 1-9. https://doi.org/10.1016/j.tranpol.2017.10.003

Min, S., So, K.K.F., \& Jeong, M. (2019). Consumer adoption of the Uber mobile application: Insights from diffusion of innovation theory and technology acceptance model. Journal of Travel \& Tourism Marketing, 36(7), 770-783. https://doi.org/10.1080 /10548408.2018.1507866 
Mutiarin, D. (2019). How do government regulations and policies respond to the growing online-enabled transportation service (OETS) in Indonesia, the Philippines, and Taiwan? Digital Policy, Regulation and Governance, 21(4), 419-437. https://doi .org/10.1108/DPRG-01-2019-0001

Nguyen-Phuoc, D.Q., Nguyen, H.A., De Gruyter, C., Su, D.N., \& Nguyen, V.H. (2019). Exploring the prevalence and factors associated with self-reported traffic crashes among app-based motorcycle taxis in Vietnam. Transport Policy, 81, 68-74. https://doi.org/10.1016/j.tranpol.2019.06.006

Nguyen-Phuoc, D.Q., Oviedo-Trespalacios, O., Nguyen, T., \& Su, D.N. (2020). The effects of unhealthy lifestyle behaviours on risky riding behaviours - A study on app-based motorcycle taxi riders in Vietnam. Journal of Transport \& Health, 16, 100666. https://doi.org/10.1016/j.jth.2019.100666

Nguyen-Phuoc, D.Q., Su, D.N., Tran, P.T.K., Le, D.-T.T., \& Johnson, L.W. (2020). Factors influencing customer's loyalty towards ride-hailing taxi services - A case study of Vietnam. Transportation Research Part A: Policy and Practice, 134, 96-112. https://doi.org/10.1016/j.tra.2020.02.008

Nordfjærn, T., Egset, K.S., \& Mehdizadeh, M. (2019). “Winter is coming”: Psychological and situational factors affecting transportation mode use among university students. Transport Policy, 81, 45-53. https://doi.org/10.1016/j.tranpol.2019.06.002

Parasuraman, A., Zeithaml, V.A., \& Malhotra, A. (2005). E-S-QUAL: A multiple-item scale for assessing electronic service quality. Journal of Service Research, 7(3), 213-233. https://doi.org/10.1177/1094670504271156

Pedersen, T., Friman, M., \& Kristensson, P. (2011). The role of predicted, on-line experienced and remembered satisfaction in current choice to use public transport services. Journal of Retailing and Consumer Services, 18(5), 471-475. https:// doi.org/10.1016/j.jretconser.2011.06.013

Sánchez, P.M., Carlos, G.A.J., María, M.C.G., \& Sánchez, F.R. (2007). Effects of service quality dimensions on behavioural purchase intentions: A study in public-sector transport. Managing Service Quality: An International Journal, 17(2), 134-151. https://doi.org/10.1108/09604520710735164

Shaaban, K., \& Kim, I. (2016). Assessment of the taxi service in Doha. Transportation Research Part A: Policy and Practice, 88, 223-235. https://doi.org/10.1016/j tra.2016.04.011

Silalahi, S.L.B., Handayani, P.W., \& Munajat, Q. (2017). Service quality analysis for online transportation services: Case study of GO-JEK. Procedia Computer Science, 124 , 487-495. https://doi.org/10.1016/j.procs.2017.12.181

Sirgy, M.J., Efraty, D., Siegel, P., \& Lee, D.-J. (2001). A new measure of quality of work life (QWL) based on need satisfaction and spillover theories. Social Indicators Research, 55(3), 241-302. https://doi.org/10.1023/A:1010986923468

Su, D.N., Nguyen-Phuoc, D.Q., \& Johnson, L.W. (2019). Effects of perceived safety, involvement and perceived service quality on loyalty intention among ridesourcing passengers. Transportation. https://doi.org/10.1007/s11116-019 $-10058-\mathrm{y}$ 
Suatmadi, A.Y., Creutzig, F., \& Otto, I.M. (2019). On-demand motorcycle taxis improve mobility, not sustainability. Case Studies on Transport Policy, 7(2), 218-229. https://doi.org/10.1016/j.cstp.2019.04.005

Suhartanto, D., Chen, B.T., Mohi, Z., \& Sosianika, A. (2018). Exploring loyalty to specialty foods among tourists and residents. British Food Journal, 120(5), 1120-1131. https://doi.org/10.1108/BFJ-09-2017-0485

Suhartanto, D., Helmi Ali, M., Tan, K.H., Sjahroeddin, F., \& Kusdibyo, L. (2019). Loyalty toward online food delivery service: The role of e-service quality and food quality. Journal of Foodservice Business Research, 22(1), 81-97. https://doi.org/10.1080/ 15378020.2018.1546076

van Lierop, D., Badami, M.G., \& El-Geneidy, A.M. (2018). What influences satisfaction and loyalty in public transport? A review of the literature. Transport Reviews, 38(1), 52-72. https://doi.org/10.1080/01441647.2017.1298683

van Lierop, D., \& El-Geneidy, A. (2016). Enjoying loyalty: The relationship between service quality, customer satisfaction, and behavioral intentions in public transit. Research in Transportation Economics, 59, 50-59. https://doi.org/10.1016/j .retrec.2016.04.001

Vicente, P., Sampaio, A., \& Reis, E. (2020). Factors influencing passenger loyalty towards public transport services: Does public transport providers' commitment to environmental sustainability matter? Case Studies on Transport Policy, 8(2), 627-638. https://doi.org/10.1016/j.cstp.2020.02.004

Weng, G.S., Zailani, S., Iranmanesh, M., \& Hyun, S.S. (2017). Mobile taxi booking application service's continuance usage intention by users. Transportation Research Part D: Transport and Environment, 57, 207-216. https://doi .org/10.1016/j.trd.2017.07.023

Zhao, J., Webb, V., \& Shah, P. (2014). Customer loyalty differences between captive and choice transit riders. Transportation Research Record: Journal of the Transportation Research Board, 2415, 80-88. https://doi.org/10.3141/2415-09 